\title{
TOURIST PREFERENCES AND EXPECTATIONS IN HEALTH TOURISM OF BAN THUNG PRADU, PRACHUAP KHIRI KHAN PROVINCE, THAILAND
}

\author{
Nalin Simasathiansophon \\ Suan Sunandha Rajabhat University, Bangkok, Thailand
}

This research aims to study tourist preferences and expectations in health tourism of Ban Thung Pradu. Tourist motivation is divided here into push and pulls types of motivation. The research also analyzed service marketing mix (7Ps) which is affecting tourist decisions to travel to Ban Thung Pradu. The population of this study consisted of those tourists who visited Ban Thung Pradu recently. Probability sampling method and simple random sampling were used to select the sample group. There were 69 samples in this research. The questionnaire was used to collected data from the sample. Questions covered various sides of tourist motivation and service marketing mix. The results show that learning new experience from a new environment has the most influence on tourist decision-making. Further motivations influencing decision-making include the reward received after hard work, spending time with friends, having good vacation time, and participating in an interesting activity respectively. Decision-making in terms of activity was affected by motivation the most. This was, probably, because of the interesting activities involved, good home stay, and professionalism of the service providers in Ban Thung Pradu.

Keywords: health tourism; motivation; service marketing mix; tourist preferences; Thailand

\section{Introduction}

Tourism industry is becoming a backbone of many economies around the world. An increasing number of tourists are contributing high revenues to countries. At the same time, the capacity of tourism destinations needs to be developed further in order to match with tourists' demand. To achieve this, public and private sectors should work together to maximize national market share in the pie of world tourism.

Due to the changing behavior of tourists and also changing trends in tourism, sustainability tourism first and foremost, a new tourist group has emerged. This group of

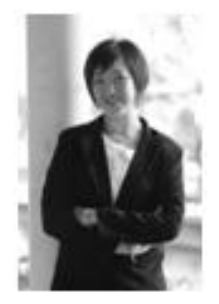

\section{Nalin Simasathiansophon}

MBA, PhD candidate, lecturer in International College Suan Sunandha Rajabhat University, Bangkok, Thailand.

Research interests include - integration process in South-East Asia, educational issues of national competitiveness, development of professional methods for entrepreneur skills development

E-mail: nalin.si@ ssru.ac.th 
tourists focuses on the experience learnt while travelling to new places or participating in the activities together with a local community.

Among these new trends, health tourism is becoming popular in Thailand. This type of tourism provides a chance to travel and to improve health at the same time. Consequently, a number of new health-promoting services have emerged.

Thai government has been actively promoting health tourism at both domestic and international markets. Other private sectors, such as private hospitals, for example, are also actively responding to this policy by offering healthcare and beauty treatment options in their variety. Local communities are not standing aside as they are providing healthcare services, such as Thai massage and spa.

Previous research studies on this subject matter have found that there is a need to develop tourism destinations in the major cities in the southern part of Thailand. These cities, according to the available statistical data, have good natural resources for promoting health tourism. This especially concerns those cities located on the west coastline of the Thai Gulf and have a high potential to become health tourism destinations due to the obvious natural factors. However, the effectiveness of their marketing campaigns is very low, primarily due to poor management factors.

Therefore, in order to develop the potential of these tourism destinations above, the researcher conducted this study on tourists' preferences and expectations while visiting these places. The results of this study may help with increasing the competitiveness of those local communities and of the nationwide tourism market overall.

\section{Literature Review}

\section{Health tourism defined}

Health tourism refers to tourism travelling to other places with the purposes of improving one's health through participation in various healthcare activities, such as medical checks, cosmetic or other surgeries, various types of physical recovery (Mueller \& Kaufmann, 2001).

The Tourism Authority of Thailand (TAT) defines health tourism according to the objectives of this type of activity:

1. Health promotion tourism refers to travelling from one place to another in order to learn local life, nature and culture. This involves offering healthcare standardized services, within and outside accommodation.

2 Health healing tourism refers to travelling to a place that is prepared particularly for health healing, such as local communities with specific natural environment or standardized hospitals.

Health tourism in general refers to travelling for the purposes of treating health, improving physical as well as mental health through health-related activities. These activities may in many cases include spa and massage (Tantivetchakul, 2003).

\section{Health tourism in Ban Thung Pradu}

From a broad perspective, health tourism in Thailand has been promoted according to the country's strategic plan. This plan has been identified as "Thailand as a world-class healthcare destination" (Department of Trade Negotiations, 2011). 


\section{TOURIST PREFERENCES AND EXPECTATIONS}

During 2013-2015, Thailand experienced a 7\% growth in health tourism alone. In money terms, this accounted for 3.2 trln baht, which made Thailand ranked $13^{\text {th }}$ at the world market and $4^{\text {th }}$ in Asia region (Advanced Business Magazine, 2017).

Such a growing trend is yet another confirmation of the fact that health tourism is becoming popular both domestically and internationally.

However, in Thailand mostly large cities like Bangkok, Phuket, Pattaya, and Chiang Mai have become final destinations for tourists. Other cities of this country still receive significantly less attention from tourists. In order to increase the number of incoming tourists from abroad, the government is trying to promote tourism in other, yet unseen cities.

Among these new and original destinations, Prachuap Khiri Khan province is very prominent as it is rich in various natural resources, such as sea, mountains, reserved forest, attractive coastline etc.

The area of Prachuap Khiri Khan is connected by Petchkasem road which is one of four major highways in Thailand and it is also located near Asian highway AH2 (Department of Rural Roads, 2013). This province has well developed transportation, such as public buses, train, and private cars. Thus, the province has a high potential to become a popular tourism destination.

According to Siriwan (2019), Ban Thung Pradu, Thap Sakae District, Prachuap Khiri Khan Province is a tourist attraction operated by the community. This community manages the attraction using a resource-based plan of its own.

All operational processes rely on the local characteristics, the philosophy of sufficient economy, smart management of resources and of the environment, with the final aim - to develop and maintain sustainable community-based health tourism.

The researcher found that there are four types of health tourism activities actively promoted in this community: body relaxation, healthcare promotion, healing, and rejuvenating.

\section{Research objectives}

1. To study motivation affecting tourists' decision to travel to Ban Thung Pradu.

2. To apply the method of service marketing mix in the process of analyzing tourists' decision to travel to Ban Thung Pradu.

\section{Methodology}

This research is a social research study which is based on quantitative research methods. The population of our study consists of those tourists who have travelled to Ban Thung Pradu. Simple random sampling method has been used to select the final sample from the overall population. Questionnaires were used to collect data.

These questionnaires were designed as a group of questions with multiple choices. The questions covered various aspects of motivation and also service marketing mix. The questionnaire has been first tested for the construct validity using the pilot testing method. Then it has been tested for reliability, and the result was from .775 to .941 .

The statistics parameters used in this research are: frequency, percentage, and multiple regression. 


\section{Findings}

In terms of service marketing mix, the result shows that service marketing mix influenced mostly on price decision, as this result is accounting for $53.3 \%$. The second in rank goes location decision which accounts for $46.9 \%$. The third in rank is safety decision, accounting for $44.9 \%$. Facilities, time worthiness, and service providers were the $4^{\text {th }}, 5^{\text {th }}$, and $6^{\text {th }}$ in ranks accordingly, thus accounting for $44.6 \%, 43.2 \%$, and $34.6 \%$ respectively.

There are four elements, however, that did not receive any influence within the service marketing mix. These are: accommodation, activities, public relation and advertising, and management.

Table 1 - Motivation affecting the tourists' decision to travel (Source: made by the author)

\begin{tabular}{|l|c|c|c|c|}
\hline \multicolumn{1}{|c|}{ Components } & $\mathrm{R}$ & $\mathrm{R}$ Square & Sig. & $\begin{array}{c}\text { Std. } \\
\text { Error }\end{array}$ \\
\hline Location & .615 & .379 & .001 & .814 \\
\hline Facilities & .636 & .404 & .000 & .909 \\
\hline Accommodation & .585 & .342 & .002 & .746 \\
\hline Activities & .816 & .666 & .000 & .546 \\
\hline Price & .667 & .445 & .000 & .690 \\
\hline Time worthiness & .758 & .575 & .000 & .535 \\
\hline Service providers & .756 & .572 & .000 & .626 \\
\hline Public relation and advertising & .769 & .592 & .000 & .625 \\
\hline Safety & .715 & .511 & .000 & .664 \\
\hline Management & .780 & .608 & .000 & .544 \\
\hline
\end{tabular}

Table 2 - Service marketing mix affecting tourists' decision to travel (Source: made by the author)

\begin{tabular}{|l|c|c|c|c|}
\hline \multicolumn{1}{|c|}{ Components } & $\mathrm{R}$ & $\begin{array}{c}\mathrm{R} \\
\text { Square }\end{array}$ & Sig. & $\begin{array}{c}\text { Std. } \\
\text { Error }\end{array}$ \\
\hline Location & .685 & .469 & .740 & .000 \\
\hline Facilities & .668 & .446 & .000 & .862 \\
\hline Accommodation & .662 & .438 & .000 & .678 \\
\hline Activities & .658 & .433 & .000 & .700 \\
\hline Price & .730 & .533 & .000 & .622 \\
\hline Time worthiness & .658 & .432 & .000 & .608 \\
\hline Service providers & .588 & .346 & .000 & .762 \\
\hline Public relation and advertising & .596 & .356 & .000 & .772 \\
\hline Safety & .670 & .449 & .000 & .693 \\
\hline Management & .601 & .361 & .000 & .683 \\
\hline
\end{tabular}

Our results demonstrate that tourists' decision to travel to Ban Thung Pradu was mostly affected by the activities offer produced by the local community, as this accounts for $66.6 \%$. The second in rank goes management system that drives tourists' decisions, it accounts for 


\section{TOURIST PREFERENCES AND EXPECTATIONS}

$60.8 \%$. Public relation and advertisement is ranked third in relation to tourists' decisionmaking. It accounts for $59.2 \%$. Time worthiness also influenced tourists' decision to travel, accounting for $57.5 \%$.

The last type of motivation affecting tourists' decision to travel was accommodation which accounted for only $34.2 \%$.

\section{Conclusions and Recommendations}

Motivation can influence tourists' decision to travel to Ban Thung Pradu. Especially when those tourists travel with friends, as this factor can increase their motivation to travel. Facilities provided by the local community increase the effectiveness of relaxation. Accommodation and professionalism of the local service providers influence tourists' decision to travel to Ban Thung Pradu.

Moreover, management system and high level of safety in Ban Thung Pradu area also encouraging people to travel to this destination. In terms of service marketing mix, the price factor is ranked first in terms of influence. Since facilities provided by service providers in Ban Thung Produ are overall efficient, the place factor of the service marketing mix affects tourists' decision to travel.

Furthermore, the product factor of service marketing mix also affects the price decision because the price of participating in each activity in Ban Thung Pradu is relatively low when comparing with other health tourism destinations in Thailand.

\section{Acknowledgement}

This research would not be possible without the support of many people. The author would like to thank Assistant Professor, Dr. Krongthong Khairiree who offered valuable assistance, support and guidance for this paper. Special thanks also to Associate Professor Tassanee Siriwan for giving insightful suggestions on interview questions. I would also like to show the greatest appreciation to Thung Pradu Tourism Community Group for providing information on the local health tourism trends and insights about the local community management system.

Furthermore, I would like to express gratitude to Suan Sunandha Rajabhat University for the support in terms of both funding and suggestions at every step.

Last but not least, I want to thank my parents for their endless love and support for this paper.

\section{References:}

Advanced Business Magazine (2017). Business Trend "Wellness tourism" in Thailand that people who are looking for a business "should read". Retrieved from: http://www.advancedbizmagazine.com/wellnesstourism/

Department of Rural Roads (2013). Amazing of Thai coastal Road. Retrieved from: http://www.drr.go.th/sites/default/files/attachment/vi_travel/8_petburi.pdf

Department of Trade Negotiations (2011). Service business: spa and massage. Bangkok: Department of Trade Negotiations, Ministry of Commerce.

Mueller, H. \& Kaufmann, E. L. (2001). Wellness tourism: market analysis of a special health tourism segment and implications for the hotel industry. Journal of Vacation Marketing, 7(1), 5-17. 
Siriwan, T. (2019). Potential of community-based health tourism: case study of Ban Thung Pradu, Prachuap Khiri Khan Province. Bangkok: Suan Sunandha Rajabhat University.

Tantivetchakul, P. (2003). Health Tourism. TAT Review Magazine, 22(1), 30-41.

Paper submitted

Paper accepted for publishing

Paper published online
21 March 2020

19 May 2020

O2 June 2020 